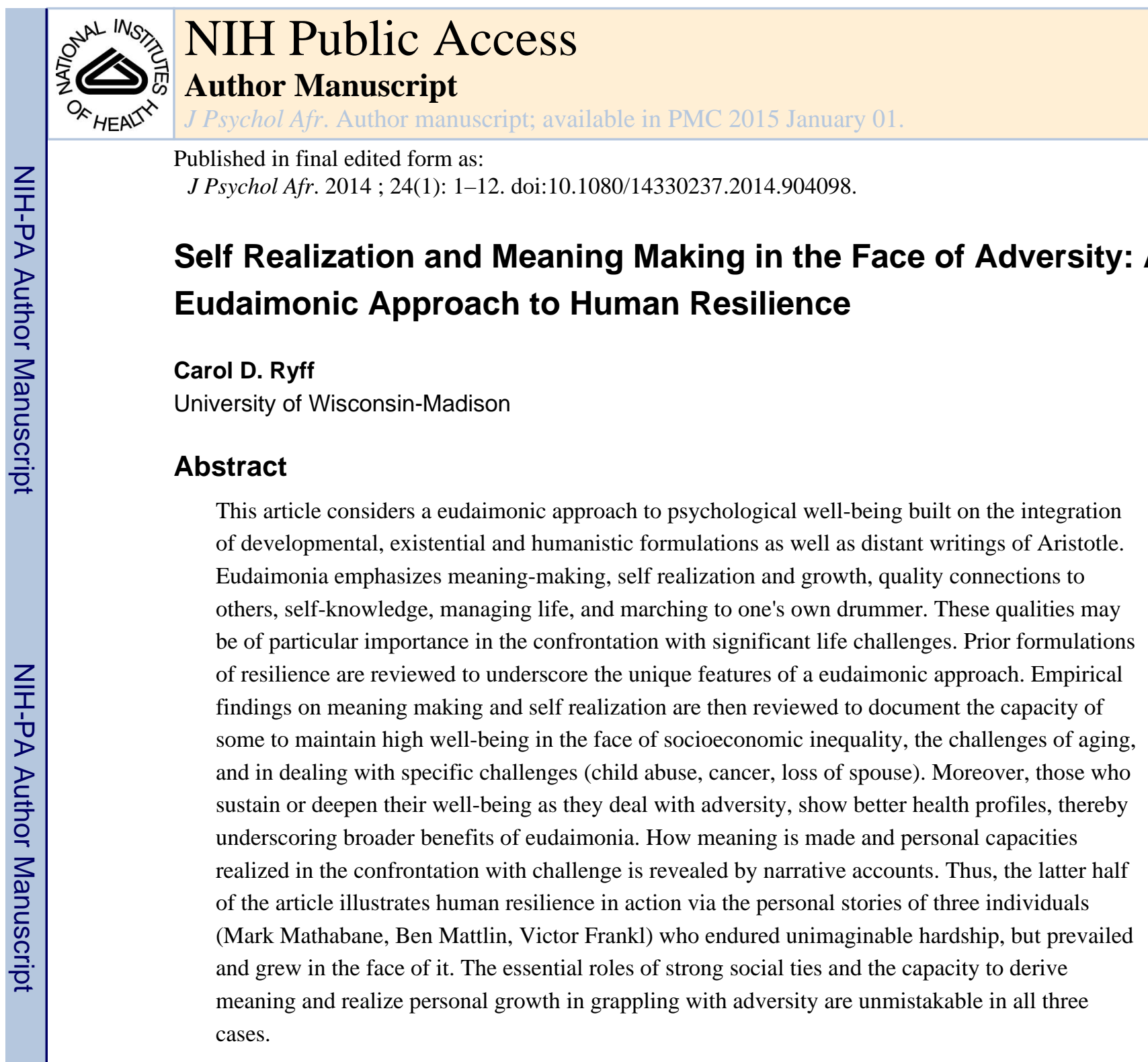

The topic of human resilience has been extensively investigated and multiple conceptions have been put forth. Although the importance of social relationships has been repeatedly stressed in prior conceptions of resilience, these formulations have given limited attention to essential activities of meaning making and self realization in the confrontation with life adversity. This article puts forth a perspective of human resilience derived from a eudaimonic approach human well-being, which is rooted in development, existential, and humanistic approaches. The first section below provides a brief look at prior formulations of human resilience, as they bring into high relief the unique features of a eudaimonic approach, particularly its emphasis meaning making and self realization. Translating these conceptual ideas to empirically tractable questions is critical for scientific advancement. Thus, the next section summarizes diverse empirical findings showing that many individuals are capable of maintaining, or regaining high eudaimonic well-being vis-à-vis various life challenges. In addition, this research underscores a further theme, namely, the health benefits linked with eudiamonia in contexts of adversity. These include dealing with social inequalities, the difficulties that accompany aging, and targeted life challenges (child abuse, cancer, loss of spouse). The latter half of this article focuses on case examples of resilience, using actual lives and personal narratives. These accounts bring to life the remarkable 
capacities some have shown in finding meaning in situations of dramatic adversity as well as in using their hardship to fuel realization of personal capacities. Collectively, the three illustrations deepen appreciation of Nietzsche's (1889) observation, "From life's school of war: what does not kill me makes me stronger."

\section{Varieties of Resilience}

\section{Initial Studies and Subsequent Elaborations}

Early studies of resilience focused on children living under adverse conditions. Rutter (1987) found that many children of mentally ill parents did not themselves become mentally ill, or exhibit maladaptive behaviors. He construed resilience as positive adaptations to stress and adversity (Rutter, 1990). Similarly, Garmezy studied children of schizophrenic mothers (Garmezy, 1974; Masten, Best, \& Garmezy, 1990) and children of poor families living (Garmezy, 1991; Garmezy, Masten, \& Tellegen, 1984), some of whom were judged by teachers and peers to be competent and without behavior problems. Werner, another early resilience researcher, followed a cohort of children born into poverty and troubled family environments, about a third of whom grew up to be competent, confident, caring adults (Werner, 1995; Werner \& Smith, 1977, 1992). Her conception of resilience emphasized sustained competence under stress.

Later studies elaborated meanings of resilience in childhood and adolescence (Luthar, 1991; Masten, 1989, 1991) and gave increased attention to a personality configuration of resilience (Robins, John, Caspi, Moffitt \& Stouthamer-Loeber, 1996). Klohnen (1996) framed resilience in adulthood as a personality profile that allows individuals to adaptively encounter and shape their life circumstances. Staudinger, Marsiske, \& Baltes (1995) emphasized reserve capacity and continued growth as components of resilience in old age. Along the way, distinctions between resilience as recovery versus resilience as thriving gained attention (Carver, 1998; Epel, McEwen, \& Ickovics, 1998). Resources thought to facilitate resilience were delineated and found to include positive emotions (Lyubormirsky \& Della Porta, 2010; Ong, Fuller-Rowell, \& Bonanno, 2010), personal intelligence (Mayer \& Faber, 2010), self-complexity (Rafaeli \& Hiller, 2010), religion and faith (Pargament \& Cummings, 2010), and social support (Helgeson \& Lopez, 2010). Such qualities paralleled the protective resources identified in the early studies of resilient children, such as high IQ, social support, personality characteristics, family cohesion and warmth, and positive selfconcepts.

Recent formulations have underscored ecological models of resilience, which emphasize children's social worlds from proximal influences of caregivers to more distal influences of neighborhoods (Ungar, 2013). Luthar (2006) has also emphasized protective and vulnerability factors within the child, the family, and the community. The first formal handbook on resilience (Reich, Zautra, \& Hall, 2010) further expanded the topic to include ethnic and cultural conceptions of resilience, while acknowledging the longstanding debate over how to best define resilience (Luthar, Cicchetti, \& Becker, 2000). The editors concluded that resilience is best formulated as the successful adaptation to adversity, which includes recovery (how people bounce back from challenge) and sustainability (the capacity to continue forward in the face of adversity). 
Taken together, this prior literature offers a useful vantage point from which to distil the uniqueness of eudaimonic approach to resilience. Most notably missing in above formulations is the essential importance of meaning making - that is, finding, and frequently creating, meaning in one's confrontation with significant life challenge. Such actions represent higher order human capacities for transforming pain or loss into sources of insight and deepened understanding of self and others. Also missing from many accounts of human resilience are the ways in which adversity is exploited to facilitate personal growth. Growth in the aftermath of trauma, crisis, or suffering has been elaborated in other literatures (Park, 1998; Tedeschi \& Calhoun, 1995; Tedeschi, Park, \& Calhoun, 1998), but the framing of such growth is different from the realization of personal capacities and talents emphasized in the eudiamonic approach described below.

\section{Eudaimonia and Human Resilience}

Eudaimonia is a term traceable to Aristotle's Nichomacean Ethics (translated by Ross, 1925), written in 350 B.C. to describe the highest of all human goods (see Ryff \& Singer, 2006). He argued that the highest of human goods was not about satisfying appetites or finding pleasure, but instead, was about "activity of the soul in accordance with virtue" (Aristotle/Ross, 1925, p.11). Aristotle's conception of virtue underscored the importance of finding balance (that which is intermediate) in all modes of conduct, thereby avoiding extremes, such as between undue humility and excess vanity, or between being a boor and a buffoon. In addition, virtue involved finding and actively striving to achieve the best that is within us. Thus, eudaimonia was a form of self-realization, played out individually, each according to personal dispositions and talents. David Norton's Personal Destinies (1976) distilled Aristotle's ethical doctrine as the obligation each person has to know and live in truth with his or her daimon (a kind of spirit given to all at birth), thereby progressively actualizing innate possibilities. Eudaimonia thus translates to meaningful living conditioned on self-truth and self-responsibility; hence, the essence of the two great Greek imperatives: to know thyself and to become what you are.

Although Aristotle's thinking is bedrock for understanding eudaimonia, numerous later perspectives contributed conceptual guides (see Ryff, 1985, 1989)for the model of psychological well-being described herein. Some came from early formulations of human growth and development (Bühler, 1935; Bühler \& Massarik, 1968; Erikson, 1959; Neugarten, 1968, 1973), which articulated the developmental tasks and challenges that individuals confront at different life stages. In addition, ideas from existential and humanistic psychology (Allport, 1961; Frankl \& Lasch, 1959/1992; Maslow, 1968, Rogers, 1962) were used to distil the importance of finding meaning and purpose in a life that is sometimes horrific. Formulations from clinical psychology that attempted to define mental health in positive terms (Jahoda, 1958; Jung, 1933) rather than as the absence of dysfunction were helpful in delineating key components of well-being. Finally, utilitarian philosophers, such as John Stuart Mill (1893/1989), offered valuable reminders that happiness itself is not the ultimate end, but rather is a byproduct of a well-lived life. Bertrand Russell (1930/1958), in turn, reminded that happiness is something that requires work and hard work; further, in his view, it follows mostly from zest (active interest and engagement in life) and affection (meaningful bonds of love with others). 
The central challenge in working with this rich array of ideas was to integrate them into a coherent whole. Many perspectives emphasized similar themes and these points of convergence became the basis for six core dimensions of psychological well-being with conceptual underpinnings from the above literatures. Self-acceptance, reflects the Greek imperative to know ourselves, although positive self-regard was also emphasized as a central feature of mental health (Jahoda), a characteristic of self-actualization (Maslow), optimal functioning (Rogers), and maturity (Allport) as well as part of self-development (Erikson, Neugarten) and individuation (Jung), which included knowing one's dark side (the shadow). Positive relations with others reflects the formulation of the interpersonal realm as a central feature of a well-lived life (Aristotle), a key component of mental health (Jahoda), the empathy and affection that embodies self-actualization (Maslow), warm relating to others as a key criterion of maturity (Allport), and Erikson's stages of intimacy (achieving close union with others) and generativity (caring about and guiding others). Both Mill and Russell wrote at length about the central importance of friendship and love in finding happiness. Personal growth comes closest to Aristotle's eudaimonia, given its explicit emphasis on realization of each individual's potential. This part of well-being involves a continual process of developing. Self-actualization (Maslow) was centrally concerned with realizing one's personal potential and the fully functioning person (Rogers) involved continually becoming rather than achieving a fixed state. Life-span theories (Bühler, Erikson, Neugarten, Jung) also gave explicit emphasis to the confronting of new challenges at different life periods.

Purpose in life drew heavily on existential perspectives, especially Frankl's search for meaning in the face of life's travails. Creating meaning and direction is also fundamental to the challenge of living authentically (Sartre, 1956). Less tuned to darkness, Russell's emphasis on zest involved an actively engaged and reflective stance toward life. Mental health explicitly included having beliefs that give one a sense of purpose and meaning. Maturity (Allport) also involved a comprehension of life's purpose. Developmental formulations, in turn referred to changing purposes or goals, such as being productive in midlife, while turning inward toward emotional integration in later life. Environmental mastery is closely aligned with a key characteristic of mental health (Jahoda), namely the capacity to choose or create a living environment suitable to one's needs. Life-span developmental theories (Neugarten) emphasized the ability to control and manipulate complex environments, especially in midlife as well as to act on and change the surrounding context. Maturity (Allport) involved the capacity to extend oneself into significant spheres of endeavor. Thus, active participation in and mastery of one's surrounding environment are key elements of well-being. Finally, autonomy invokes qualities such as self-determination, independence, and the regulation of behavior from within. Self-actualizers (Maslow), for example, showed an internal locus of evaluation and a resistance to enculturation. The fully functioning person (Rogers) did not look to others for approval but evaluates oneself by personal standards. Individuation (Jung) involved a deliverance from convention in which one no longer subscribes to the collective beliefs and fears of the masses. Life-span developmentalists (Erikson, Neugarten, Jung) described turning inward in the later years, when one gained a freedom of the norms governing everyday life. Autonomy is thus a notably Western aspect of well-being. 
How these dimensions of psychological well-being relate to resilience needs clarification. A first point is that the separate components serve as useful tools for gauging the upside of how individuals fare in their struggle with adversity or challenge. Some individuals, as detailed in the next section, show a capacity to maintain high eudaimonic well-being, even though they are confronted with difficult life challenges. Thus, akin to early formulations of resilience as adaptive functioning in the face of hardship, the components of eudaimonic well-being delineate the scope and nature of how one is functioning in the face of challenge. Two aspects, purpose in life and positive relations with others, are the focus of this special issue, but the others are included as well to underscore the multiplicity of strengths humans exhibit in their life journeys.

Second, the eudaimonic approach to resilience asserts that well-being is sometimes honed and nurtured via active engagement with adversity. Personal growth, which involves the capacity to realize one's talent and potential, often involves encounters with obstacles, failure and disappointment. Such experiences require finding inner strengths and resources of renewal. While personal capacities may be deepened, self-knowledge may also be expanded, including paradoxically, awareness of one's limitations and vulnerabilities. Similarly, positive relations with others may be enriched in encounters with life difficulties, be they the struggles of aging parents, or the difficulties of growing children. Indeed, interpersonal flourishing in most lives is about the complex mix of positive and negative emotions, which comprise our most significant human ties. Purpose in life, as articulated by Frankl, is fundamentally about meaning-making in the face of trauma. Thus, across the six dimensions, a key point is that eudaimonic well-being is often forged in the crucible of adversity. The next section distils empirical evidence that some individuals are able to maintain, or regain, their eudaimonic wellbeing in the face of adversity and further underscores the health benefits, which accompany a meaning-making, growth-oriented outlook on life.

\section{Empirical Examples of Resilience and Their Relevance for Health}

Resilience demands a focus on hardship or adversity; i.e., some kind of life challenge. Many of the examples described below are taken from a national study of U.S. adults known as MIDUS (Midlife in the U.S.). They revolve around three kinds of encounters with the negative: socioeconomic inequalities, challenges of aging, and targeted life stressors. The examples were selected to showcase recent findings from a national study of U.S. adults as well as other new longitudinal findings. Most studies included utilize eudaimonic measures of well-being as in their formulation of protective resources.

\section{Challenges of Inequality}

It has become well-established that low socioeconomic status (SES), measured in terms of income, occupational status, or educational attainment, increases risk for poor health (Adler $\&$ Steward, 2010). However, not all economically or educationally disadvantaged individuals succumb to this grim prediction, and increased interest is given to those who defy the SES gradient in health. A study by Morozink, Friedman, Coe, and Ryff (2010) first showed that educational status is associated with a marker of inflammation known as IL-6 (Interluekin -6), which is a precursor to multiple disease outcomes (cardiovascular disease, 
rheumatological disease, Alzheimer's disease, osteoporosis). As hypothesized, those who were educationally disadvantaged showed higher levels of this biological risk factor, on average. However, there was variability in the eudiamonic well-being among those with only a high school education or less, such that some showed high levels of purpose in life, environmental mastery, self-acceptance, and positive relations with others, despite their low educational status. Importantly, high well-being moderated the effect of educational standing on IL-6. That is, among those dealing with limited educational attainment, those with higher levels of eudaimonic well-being did not show elevated levels of inflammation compared to their low education peers. Such findings suggest that well-being may serve as a buffer against the adverse effects of low SES on inflammatory risk.

A related MIDUS study focused on the experience of socioeconomic adversity in early life, which is known to predict poorer health in adulthood (Cohen, Janicki-Deverts, Chen, \& Matthews, 2010). Illustrating resilience, Miller, Lachman, Chen et al., (2011) showed that many individuals, despite growing up in impoverished environments, do not exhibit health problems in midlife, assessed in terms of metabolic syndrome (a cluster of cardiovascular risk factors, including central adiposity, high fasting glucose, high blood pressure, and dysregulated lipids). They found that middle aged individuals who grew up in low socioeconomic environments did not have higher prevalence of metabolic syndrome if they had received high maternal nurturance in childhood. A related study (Chen, Miller, Lachman, Gruenewald, \& Seeman, 2012) found that adults from low childhood SES environments who engaged in various cognitive and emotional strategies ("shift and persist") in response to life stressors also did not exhibit elevated allostatic load, a composite of multiple physiological markers reflecting wear and tear of different biological systems.

Earlier findings from MIDUS also documented the psychological strengths evident among some who had only a high school education (Markus, Ryff, Curhan, \& Palmersheim, 2004). Open-ended interviews revealed unique personal profiles among these educationally disadvantaged who nonetheless had high eudaimonic well-being: above all, they were interpersonally oriented - that is, concerned about caring for others and upholding their responsibilities to others. A further study focused on majority/minority status comparisons (Ryff, Keyes, \& Hughes, 2003), and found that minority status predicted higher psychological well-being (multiple dimensions) than majority status (after adjusting for age, gender, educational attainment). These unexpected effects were even more pronounced when perceived discrimination was controlled. Such findings suggested that the challenges of minority life in the U.S. seemed to hone psychological strengths, such as life purpose and personal growth.

In sum, the MIDUS study provides evidence of resilience in the face of social inequalities (see Ryff et al., 2012 for further examples). Among educationally or economically disadvantaged individuals, some have high profiles of eudaimonic well-being as well as other cognitive and emotional resources. Increasingly, evidence shows that these factors are protective buffers against risk of poor health, measured in terms of regulation of diverse physiological systems. 


\section{Challenges of Aging}

For most individuals, the process of growing old poses notable challenges. Normal biological aging (of cells, tissues, organs) is often accompanied by increased risk of multiple diseases (type 2 diabetes, Alzheimer's disease, cancer, cardiovascular disease) (Center for Disease Control and Prevention, 2011) as well as increased chronic conditions (e.g., hypertension, arthritis, dysregulated lipids). Second, some aspects of psychological wellbeing (especially purpose in life and personal growth) have shown sharply downward trajectories from midlife to old age (Keyes, Shmotkin, \& Ryff, 2002; Ryff, 1989; Ryff \& Keyes, 1995; Springer, Prudrovska \& Hauser, 2011). Nonetheless, there is considerable variability surrounding average patterns of psychological decline. Some older persons do not fit the average profile; indeed, they show levels of physical and mental health comparable to younger age groups. Further, even when significant health changes occur, many older persons consider themselves to be aging well (McLaughlin, Connell, Heeringa, Li, \& Roberts, 2010).

With data from MIDUS, Friedman and Ryff (2012) showed that having multiple chronic conditions (co-morbidity) was common among older members of the sample. Increased chronic conditions were accompanied by higher levels of inflammatory markers, such as IL-6 and C-reactive protein (CRP), thus illustrating the pernicious spiral (each influences the other) that exists between health problems and inflammation. Even so, among older adults who reported higher levels of purpose in life and positive relations with significant others, higher chronic conditions were not linked to elevated inflammation. Thus, high life engagement appeared to serve as a protective resource, thereby reducing the risk of future disability and mortality for these individuals. A related study from MIDUS (Cotter \& Lachman, 2010) found that physical health decline with aging was significantly reduced among those with positive profiles on three protective factors (control beliefs, social support, physical exercise).

Other investigations from MIDUS have shown that volunteering and making charitable donations has positive effects on psychological well-being among those age 55 and above, possibly attributable to the sense of self-efficacy, altruism, or the desire to do good deeds. Similarly, Greenfield and Marks (2004) found that formal volunteering was associated with more positive affect among older adults; volunteering also mitigated against declines in purpose in life linked with loss of major social roles. Greenfield (2009) found that greater felt obligation to help close others also protected against depressive symptoms as well as declining personal growth and self-acceptance. Finally, Seeman et al. (2011) linked social contact and support to cognitive abilities and found that those with greater contact and support had higher executive function and better episodic memory, whereas decline in social measures was associated with negative cognitive profiles, especially among younger adults.

The Rush Memory and Aging Project, a community-based epidemiological study, has generated similar positive findings. A first investigation found that those with higher levels of purpose in life at baseline were less likely to die seven years later (Boyle, Barnes, Buchman, \& Bennett, 2009), net of numerous confounds (depressive symptoms, chronic conditions, income). A second study showed that higher in purpose in life at baseline was protective against mild cognitive impairment as well as Alzheimer's disease seven years 
later, net of confounds. Most recently, purpose in life was found to modify the association between Alzheimer's disease pathology in the brain (assessed from post-mortem analyses) and cognitive function prior to death (Boyle, Buchman, Wilson, Yu, Schneider, \& Bennett, 2012). Taken together, findings from the Rush Memory and Aging Project underscore important benefits for cognitive function among older adults with high purpose in life, including the maintenance of such abilities even when organic pathology is evident in the brain.

In sum, the preceding findings converge to show that although many persons succumb to physical and mental health decline as they age, others do not. Importantly, among those who are able to maintain high eudaimonia (e.g., active, engaged, purposeful, socially related living), risk of physical decline and cognitive deterioration are substantially reduced. Aging, in short, is an arena of dramatic individual differences, wherein those who maintain high well-being reveal notable benefits, not only in terms of their subjective experience, but also with regard to their health and functional capacities.

\section{Targeted Life Challenges}

A third category of adversity examines how individuals far in dealing with three targeted life challenges: early life abuse, adult cancer, and loss of spouse. All examples are again from the MIDUS national study of U.S. adults.

Pitzer and Fingerman (2010) investigated the adult physical and mental health consequents of severe physical abuse during childhood. Three types of psychosocial resources (emotional support, instrumental support, personal control) were also examined. Findings showed that the effects of child abuse on adult physical health and negative affect were less severe for individuals with a greater sense of agency over their lives. Greenfield and Marks (2010) linked physical and psychological abuse in childhood to psychological distress in adulthood, and further examined one's sense of community as a moderator of these effects. As predicted, high community support was protective against high distress among those who experienced abuse in childhood.

Two studies from MIDUS have considered resilience in the context of cancer. Costanzo, Ryff, and Singer (2009) examined the psychological, social, emotional and spiritual adjustment of individuals with a cancer diagnosis and compared them to a demographicallymatched comparison group of individuals without a major-illness diagnosis. Findings indicated that although depressive symptoms worsened over time among cancer survivors compared to matched controls, cancer survivors were resilient in other ways. That is, their cross-time changes in mood, psychological well-being, social well-being, and spirituality over time were similar to those observed for individuals not dealing with the challenge of cancer. Further evidence suggested that older adults were better able to deal with the challenge of a serious illness than younger cancer survivors. Prudrovska (2010), in turn, examined changes in personal growth over time among cancer survivors and a non-cancer comparison group. Although personal growth declined in the longitudinal sample overall, such decline was not evident in young adults with cancer compared to same-aged adults without cancer. For the oldest members of the sample, however, those with cancer showed accelerated decline in personal growth compared to the no-cancer comparison group. 
Resilience has been examined in the context of spousal loss. Ong et al. (2010) compared a sample of bereaved individuals who lost a spouse between Wave I and II of MIDUS to a demographically matched comparison group of continuously married individuals. Spousal loss was linked with decreasing positive emotions over time, but the effect was moderated by positive reappraisal. Those who lost a spouse and who had higher positive reappraisal profiles had less decrease in positive emotions following their loss. They also examined whether loss of spouse might be less detrimental among those who had had strained marital relationships. As predicted, those with more troubled spousal relationships at baseline were less adversely influenced by subsequent spousal loss. More recently, Ong, Fuller-Rowell, Bonanno, and Almeida (2011) found that spousal loss predicted subsequent diurnal cortisol dysregulation, with these effects partially explained by changes in positive emotion. Such findings were consistent with the theoretical framework linking emotional resilience to physical health.

In sum, the preceding studies describe multiple varieties of resilience in the face of differing life challenges. Several also document the health benefits of maintaining high well-being in such contexts. Those who were able to find meaning, experience personal growth, and enjoy good social relationships as they negotiated losses or hardship thus seemed to benefit, not only phenomenologically, but also with regard to maintaining well-regulated biological systems. These scientific findings are contrasted with case examples of resilience in the next section. The objective is to provide an inside picture on how meaning is made and human capacities are realized in the confrontation with significant adversity. The rich autobiographical accounts of resilience underscore the essential role of strong social ties as negative experience is transformed into powerful insights that fuel personal growth. Above all, the examples are intended to show how human resilience comes to be.

\section{Bringing Human Resilience to Life with Narrative Accounts}

Three lives are examined to probe inside stories of human resilience. The first is about Mark Mathabane who grew up in extreme poverty during the apartheid era in South Africa. The second is about the life of Ben Mattlin who was born with a congenital disease that was severely and progressively disabling. He nonetheless became a leader in the disability rights movement in the U.S. The third is the archetypal example of resilience, Victor Frankl, whose multiple years in Nazi concentration camps is a soaring tale meaning making and growth under the most horrific of conditions. Together, the three narratives offer breathtaking examples of how one prevails in the face of adversity.

\section{Resilience in South Africa}

Mark Mathabane's childhood adversity was chronicled in his book, Kaffir Boy (1986). The term Kaffir, Arabic in origin, is used disparagingly to refer to blacks; it is the equivalent of nigger. The eldest of seven children, his story begins with the observation that "In South Africa there is a saying that to be black is to be at the end of the line when anything of significance is to be had" (p.4). His father was a laborer earning \$10 a month, when work could be found. A terrifying part of his childhood memories were the late-night police raids, in which he was left to care for his younger siblings, while his parents had to escape, lest they be arrested for not having identification passes in order. These raids created constant 
uncertainty, and children were frequently brutalized for trying to hide or protect their parents. Repeated humiliation was central to the trauma of apartheid, which watched in his father's confrontation with police. Not a smiling man, his father forced a smile on his face. "It was a begging smile, a passive acceptance of the policeman's authority. After smiling, my father dropped his eyes to the floor. He seemed uncharacteristically powerless and contrite, a far cry from the tough, resolute and absolute ruler of the house I knew him to be, the father whose words were law" (p.22). These raids haunted Mathabane in daily life and in his dreams - "I would often wake up dreaming in the middle of the night, claiming that the police were after me with dogs and flashlights, trying to shoot me down" (p.28).

The father's arrests and absences created still worse difficulties - wages for food and rent were lost. This meant days of nothing to eat and constant threats from the landlord about eviction from their dingy shack. The malnutrition led to illnesses, which could not be treated because there was there was no money for the clinic. In desperation, Mark, his siblings, and mother dug for food at the garbage dump, searching for diseased chickens and rejected eggs from the nearby factory. At one hopeless moment, his grandmother paid the rent for another week and brought them bread, sugar, and mealie meal. Granny gave his mother money to take two younger siblings to the clinic.

Despite the deprivation, significant strengths were present. Although their world included no storybooks or nursery rhymes, Mathabane recalled his mother's stories serving as a kind of library, "a golden fountain of knowledge where we children learned about right and wrong, about good and evil" (p.79). Her mesmerizing tales and hypnotic voice left them transfixed, such that they wanted the stories never to end, imploring her to tell another. Thus, under the strain of inadequate food and shelter, numerous pregnancies, a husband who could not find work and descended into drinking and gambling, Mathabane's mother maintained her own personal strengths and her sense of hope in her children's future. She had an unwavering commitment to their education, even when it meant beatings from her husband. "I want you to go to school, because I believe that an education is the key you need to open up a new world and a new life for yourself, a world and life different from either your father's or mine. Education will open doors where none seem to exist. It'll make people talk to you, listen to you, and help you; people who otherwise wouldn't bother. It will make you soar, like a bird lifting up into the endless blue sky, and leave poverty, hunger and suffering behind" (pp. 133-134).

School became critical for Mathabane, not only for learning, but to protect him from joining youth gangs roaming the filthy streets of Alexandra in search of food and adventure. Many were lured into lives of prostitution and crime; as a consequence, many ended up in penitentiaries or in the grave. Again, Mark's mother played a critical role - when he began skipping school to return to the gangs, she intervened and sanctioned a severe beating delivered by the principal and male teachers. He spent an entire week bedridden, unable to sit up or sleep. "For the rest of my primary school years I seldom, if ever, cut school for any reason. Even when I was gravely ill, I would crawl to school, and the teachers would send me back home" (p.261). 
School provided an important source of success, in a context wherein failure and hopelessness were everywhere. When he finished number one in his class, both mother and grandmother were thrilled, happy, and proud. Still, the constant exposure to crime, violence, and even murder, took a toll. At one point, weary from hunger and beatings, Mathabane attempted suicide. Somehow his courage, fanatical will to survive and dream of a bright future deserted him. Again, the remarkable mother intervened, first reminding him how much he would be missed by his siblings, but also that she would miss him more than anyone else. "I too would want die if you were to die. You're the only hope I have. I love you very much.” (p.169). Her words provided him with a great insight that he carried for years afterward - when troubles seemed too much, he would remember how much it helps to have someone loving and understanding, to share in one's dark periods. Importantly, he saw the meaning that could follow - "life takes its true meaning in proportion to one's daily battles with suffering" (p.170).

Along the way, Granny, a gardener for wealthy white people, exposed her grandson to the outside world, first bringing comic books from the family for whom she worked, and then taking Mark into this world. His first exposures to white school children with blazers, shiny black shoes and a red-brick school house with flowerbeds, athletic fields, and swings left him stunned. Following the same-aged son from his grandmother's employers, he could not believe the luxuries (toys, bicycles, pinball machines, electric trains, shelves and shelves of books), while his people lived in abject poverty. Of course, he wondered why white people had everything and black people had nothing. He could not read so the white son announced that he was retarded, like other Kaffirs, because they had smaller brains. This comment, paradoxically, fueled a driving passion to learn to express his thoughts and feelings effectively in English. "The remark....had so wounded my ego that I vowed, whatever the cost, I would master English, I would not rest until I could read, write and speak it just like any white man, if not better. Finally I had something to aspire to.” (p.192).

Mathabane's ultimate passport to freedom came not only from his excellence in school, but from his tennis skills, for which he won scholarships that brought him onto contact with Arthur Ashe, a source of inspiration: "I marveled at how proudly he walked. I had never seen a black man walk that proudly among whites" (p.236). Ashe revealed to him the truth about the need to rise above one's own suffering, to conquer one's fears. He received more help and support from his unofficial sponsor who gave to him and his family out of the goodness of heart, without a trace of condescension.

Tennis was his route to college and international travel, where his opportunities were used to the fullest. Eventually he wrote his own remarkable story, which put the lives of apartheid before the rest of the world. Mathabane thus became a voice for the suffering of many leading wretched lives. His account revealed what deplorable conditions do to people and their essential humanity. Thousands of migrant workers forced to live hundreds of miles from their families were part of the tale. Many existed under such stress and had absorbed so much emotional pain, they became the walking dead - they were physically alive, but death had come for their minds and souls. 
For those interested in human resilience, Kaffir Boy depicts how a child confronted with relentless adversity, involving violation of basic of human needs and persistent feedback that he had no status in a strictly hierarchical world, became a scholar, talented athlete, and powerful spokesman about the horrors of apartheid. That he had strong social support from his mother and grandmother was an unmistakable strength. Both women were powerful and pivotal social resources, each contributing importantly to building his character, while also to creating opportunities for him. Inside Mathabane, however, were great personal resources as well, such as the capacity to extract meaning from his ordeal, including the appreciation of the good that can follow from suffering as well as his powerful drive to speak other languages and make the most of his talents. His commitment to his own becoming was pivotal.

\section{Resilience vis-à-vis Congenital Disease}

Ben Mattlin's book, Miracle Boy Grows Up (2012), tells the tale of a child born with spinal muscular atrophy, a disease for which he was not expected to survive childhood. He lived, but experienced numerous medical horrors and endured relentless pain and frequent humiliation. None of it, however, defeated him. From the beginning, his mother told him there was nothing he could not do, and it seems he believed her. She encouraged him to speak up, ask for what he needed, and remember that people aren't mind readers. Her message, revealing an impact on his life that was dramatic, was "light a candle instead of cursing the darkness" (p.6).

Mattlin's first diagnosis was amyotonia, a term describing lack of muscle tone. When people asked him what was wrong, he eschewed such technical terms and simply said, "I can't walk, I was born this way" (p.3). The answer was simple and sufficient. At age 4, the doctors prescribed a battery of physical treatments, involving braces that locked him into a statue-straight posture. He described it as equivalent of foot-binding in ancient Japan. Fortunately, the methods were rescinded after determining they had no value. His commentary: "In nearly every other aspect I'm a healthy and happy kid. Yet every time I catch a cold I'm at high risk for pneumonia. I can't cough with sufficient force to clear mucus from my lungs. Regardless, from an early age I refuse to think of myself as fragile. Sure, I'm floppy and I do bump my head a lot, but I always bounce back. I'm tough, resilient. I'm a survivor. The labors of my disability strengthen my character" (p. 3).

Ben's parents, ahead of their time, refused to let their son be segregated. They sent him to private school in New York because they knew separate was not equal, and they wanted the best education for him. He added, "they're also snobs" (p.15). As the only wheel-chair student, he became a pioneer of sorts. Still, he was painfully aware of basic differences, like the fact that other seven year olds could dress themselves, while he still had to rely on his parents for everything, including going to the bathroom. Spontaneity was a forbidden luxury, and impulsivity was drained out of him. Then there were accidents, like falling out of the wheelchair, as others tried to maneuver it down the school steps.

One summer and fall during his teenage years, he went through a series of operations related to spinal fusion, which involved attaching pieces of metal to his pretzel-like spine. The surgery took multiple months and was followed by a lengthy period at a convalescent 
facility. From the outset, his amazing outlook: "It's enough to make an ordinary teenager crumble, perhaps, but not me. This is my big battle, the travail I must endure to achieve stature, literally. I'm Ben-Hur facing the Roman galley ship. If he can row for three years, I can lie in an institutional bed for six months. In characteristic fashion, macho fantasies come to my rescue" (p.49). Again, his mother was masterful, with encouragement that he scribble his fears and expectations into a notebook. So doing launched his lifelong commitment to journal keeping.

Beyond disability problems, Mattlin had to deal with the difficulty of his parents' divorce and his father's remarriage, and later with his mother's ovarian cancer, from which she ultimately died during his college years. These were complex challenges for someone dealing with major disability, well before the country acknowledged and addressed the needs, and potential, of disabled persons. Nonetheless, Mattlin continued working his way through the fundamental paradoxes of his life, such as the fact that to achieve greater independence, he had to rely on hired assistance from others - something he framed as "dependent autonomy." In retrospect, he saw his challenges in managing various assistants who helped him through college and beyond as what enabled him to grow up.

Mattlin was one of the first students in a wheelchair to attend Harvard, where he was confronted with the lack of wheelchair access throughout the campus, which in turn, translated to housing problems. Then there were intractable deans and being buffeted by revolving attendants, plus difficulties manipulating books, feeling impatient and overwhelmed by the coursework, and craving ballast, which for him meant wanting a girlfriend and experiences usual for young adult things like losing his virginity. In the middle of this whirlwind of challenges, Mattlin's mother succumbed to cancer, which added a major personal loss and grief to his woes.

Nonetheless, he graduated from Harvard, and during one summer visit with his father's family, he met the nanny of his half-brother, a woman who would become his life partner. They begin living together when he is 20 . After graduation, they drove cross-country together, around the time that disability prejudice was becoming a public issue, illustrated by Marlee Matlin's acceptance of an Oscar for her role in Children of $a$ Lesser God, which portrayed the challenges of being deaf. Mattlin followed these events and participated in disability rights groups, as he and his partner settled into life on the west coast. $\mathrm{He}$ confronted numerous challenges of finding a job, but eventually became a freelance journalist and commentator.

When Ben was 26 and his partner was 29, they married. The following year, the Americans with Disabilities Act was signed into law. Mattlin's life thus paralleled the growth of the disability rights movement, for which he became an ever more prominent spokesman, given his careful observations about the difficulties confronted by the disabled and the need for more wide-ranging responses, combined with his invaluable wit. Quoting from Woody Allen (New York Times, Oct. 16, 2011), he noted, "life is a tragedy filled with suffering and despair and yet some people do manage to avoid jury duty." Such musing provided entrée to the next set of challenges he faced. 
Medical tests and his own observations revealed progression of the atrophy. "In other words, the opposite of progress. Worsening." (p.133). Absorbing the information required that he realign his life around weakening hands. His guiding mantra was "plan ahead, mourn the losses, and move on" (p.136). He accepted that it was easier for his wife to feed him dinner; it saved time and effort. He allowed someone else has to brush his hair. There were still deeper losses, related to his wife's comment that she missed his touch, his gentle caresses. This was all the more poignant as she was not one to express sorrow or disappointment or need. In his words, this woman is "a coper. She muddles through. She'd sooner ask what I want to do-and derive pleasure from doing that - than express a desire of her own. So I'm pleased she's being frank, but still her words sting." (p.137). He realizes he is hurt and scared. And yet, ".... even as the upwardly mobile, Harvard-educated man is evaporating - replaced by the severely disabled cripple - somehow I can't give up. You mourn and move on. It's a different direction but not a dead end. I'll have to adapt" (p.137).

Mattlin continues to write and do editorial work, and his wife works as well. But not ones to be limited by their circumstance, they decide to have children. That wish takes them several years through the dark maze of infertility. Finally pregnancy is achieved, and their daughter, Paula (named after his mother) is born. How does this disabled man parent? Beautifully it seems. Although he can't change diapers, or bathe, or feed his daughter, he can make up silly songs and games and tell stories. This he does with great enthusiasm, though realizing that many of his stories have a character with a deficit in the eyes of their peer group. By the end of the story, everyone learns not to reject or discount those who seem to be different.

More health challenges occur and again, they weather through. No longer in crisis mode, the family grows, a second child is born. One evening while telling a bedtime story, his thumb slips off his wheelchair controller. Despite multiple efforts by Paula to return the thumb to its place, it become clear he has lost strength in his primary digit. Now over the age of 40, progressive deterioration of SMA sets in. "You'd think I'd be used to it by now. And that thought alone gives me comfort, actually. Just when I can't take any more.... Any more weaknesses, any more limitations, any more atrophy....I realize that I can and I will. Because I always have. I always do. I have no choice.” (p.165).

His work for financial magazines dries up and money is tight. Somehow he is invited to submit a short essay to National Public Radio, and people respond immediately to his inspirational story, his optimism, and his perspective. Requests for reprints pour in and more writing for NPR ensues. He keeps pitching ideas that they accept. At some point, he is encouraged to think about something longer, beyond a 400 word essay. Other columns follow from major newspapers. Ultimately, Mattlin decides to write his memoire, despite other hospitalizations along the way.

Last page of the book is stunning. His daughters have become teenagers that amaze him daily with their intelligence, talent, beauty, and height. He is aware that progress in their lives can be derailed at any moment by another medical emergency, or any number of other disasters, but these he construes merely as interruptions. He has always been able to bounce back, although he notes that both he and his wife are growing older, more fragile. "Yet whatever happens, I know we're a good team. Deep in my osteoporotic bones and atrophied 
muscles, I feel we were designed for each other. We keep planning, mourning what's lost, celebrating what's gained, and then going on. That's just the way our lives are. Try not to be too jealous." (p.194). Ben Mattlin's story, from beginning to end, is a paean to human resilience.

\section{Resilience vis-à-vis Utter Hopelessness}

Victor Frankl endured three years in Nazi concentration camps. His book about it, Man's Search for Meaning, was written after his release over a period of 9 days and published in 1945. It became a bestseller. When the 1992 edition appeared, the book had seen 100 printings in English plus publication in 21 other languages. The English editions alone had sold more than 3 million copies. Writing a preface to the 1992 publication, Frankl observed that the fame of the book was not a statement about his accomplishments, but rather an expression of the misery of our time and the need to find meaning in the face of it - "it must be a question that burns under their fingernails" (p.11).

His goal in writing the book had been to convey, by way of a concrete example, that life holds meaning under any conditions, even the most miserable. He divided his recollections into three parts: the period after admission, the longest period when life in the camps became an entrenched routine, and the period following release and liberation. The first realization, which none could grasp upon their arrival, was that everything was to be taken away. Frankl begged to keep a roll of paper in his coat, the manuscript of a book he described to the guard as his life's work. The guard laughed and then bellowed at him. Like everyone else, the only thing he could keep was his bare body. This introduction was followed by a kind of curiosity phase, in which the new arrivals looked around and took the place in, as if their minds could somehow be detached from their surroundings. Then followed a sense of surprise as they watched themselves endure the unimaginable - finding that they could carry on even though they were unable to clean their teeth or their bodies, had insufficient food, and were subjected to brutal work.

The deeper essence of the book emerged in the second phase, when the prisoners began living an apathy that was a kind of emotional death. Frankl noticed they became less traumatized by the torture of others; eyes were no longer averted. Instead, they watched the suffering of others and were unmoved by it. Feelings were blunted, with the insensibility becoming a kind of protective shell - "A corpse stares at him with glazed eyes and he continues sipping his soup." (p.34). Hunger and lack of sleep contributed to the apathy and irritability. "Reality dimmed, and all efforts and all emotions were centered on one task: preserving one's own life and that of the other fellow" (p.40).

Physical beatings were omnipresent. As a psychiatrist, Frankl recognized that some guards among them were true sadists. Still, what caused the greatest pain in these beatings was, in his view, less the physical than the insult the beatings implied. He recalled moments when even the most hardened prisoners had their indignation aroused during a beating; it was the personal insult rather than excruciating pain that fueled such a response.

Despite so much negativity, he began seeing that some experienced a deepened spiritual life. "Sensitive people who were used to a rich intellectual life may have suffered much pain 
(they were often of a delicate constitution), but the damage to their inner selves was less" (p. 47). His own inward journey became a discovery of hidden resources. One early morning on the way to the work site, they stumbled along in the darkness over big stones and through puddles while the icy wind blew around them. Someone said, "If our wives could see us now." This comment brought to mind his wife, as the stars were fading and the light of morning was emerging. "My mind clung to my wife's image, imagining it with an uncanny acuteness. I heard her answering me, saw her smile, her frank and encouraging look. Real or not, her look was then more luminous than the sun which was beginning to rise. A thought transfixed me: for the first time in my life I saw the truth.... that love is the ultimate and highest goal to which man can aspire" (pp.48-49). For Frankl, the deeper realization, however, was that nothing could touch the strength of his love and the image of his beloved. Instead, he felt her there with him, he was able to "stretch out my hand and grasp hers" (p. $52)$.

This intensification of his inner life helped him to find refuge from the emptiness, desolation, and spiritual poverty of his existence. It allowed him to escape into the past. "In my mind, I took bus rides, unlocked the front door of my apartment, answered my telephone, switched on the electric lights. Our thoughts often centered on such details, and these thoughts could move one to tears" (p.40). In addition, he began appreciating the meager pleasures of camp life, such as having time to delouse before going to bed, feeling thankful there was no air raid alarm or loss of electric lights. If done properly, the sleep to follow would be much better. This was a kind of negative happiness, something he recalled Schopenhauer had written about as the freedom from suffering.

His insights grew and began to encompass reflections on human liberty and spiritual freedom, which he saw as ultimately about how one responds to the situation life presents. "The experiences of camp life showed that man does have a choice of action. There were enough examples, often of a heroic nature, which proved that apathy could be overcome, irritability suppressed. Man can preserve a vestige of spiritual freedom, of independence of mind, even in such terrible conditions of psychic and physical stress" (p.74). They could remember, for example, those who passed through the huts, giving comfort to others, giving away their last piece of bread. "....everything can be taken from a man but one thing: the last of the human freedoms - to choose one's attitude in any given set of circumstances" (p. 75). Here he recalled Dovstoyevski, who claimed the only thing he dreaded was to be unworthy of his own suffering. For Frankl, spiritual freedom, which could not be taken away, was what made the life there "meaningful and purposeful" (p.76). Barren of everything, high moral behavior was still possible through the attitude one held toward one's existence - "His unique opportunity lies in the way in which he bears his burden" (p.86).

These observations allowed him to sometimes shift from the daily focus about survival to another place. "I forced my thoughts to turn to another subject. Suddenly I saw myself standing on the platform of a well-lit, warm and pleasant lecture room. In front of me sat an attentive audience on comfortable upholstered seats. I was giving a lecture on the psychology of the concentration camp" (p.82). This remarkable thought sequence revealed that Frankl had not lost his faith in the future. More striking, his imagining of the future was 
that he would use his experience to enrich his work as a psychiatrist - this is what actually happened, his envisioned future came true.

Other observations revealed his insights about mind/body interactions - anticipating what would later be called psychoneuroimmunology. Frankl, as a physician trained in psychiatry, saw the linkage between hope and life or death. In 1944, in the week before Christmas and New Years, the death rate in the camp went up beyond all previous expectation. Many he believed had lived in hope that they would be liberated by this time. Instead, they lost their courage and were overcome with disappointment, which had a dangerous influence on their powers of resistance. "Those who know how close the connection is between the state of the mind of a man - his courage and hope, or lack of them - and the state of immunity in his body will understand that the sudden loss of hope and courage can have deadly effect. The ultimate cause of my friend's death was that the expected liberation did not come and he was severely disappointed. This suddenly lowered his body's resistance against the latent typhus infection" (p.84).

Following their release, Frankl observed that they were not mad with joy, indeed, they could not experience it. They came upon a meadow full of flowers, for example, but had no feelings about them. There was only a spark of joy when they saw a tail of multicolored feathers. "We had literally lost the ability to feel pleased and had to relearn it slowly" (p.95). Indeed, they were not looking for happiness; it had not sustained them, or given them courage and meaning during their ordeal. Those came from the suffering. Others found that no one awaited them, even the person whose memory had most sustained them. These losses also had to be endured.

For many, he believed the day came when they looked back on their experience and could not understand how it had all been endured. In Frankl's case, the trauma was used to develop logotherpay, which is a kind of psychological intervention designed to help individuals find meaning in their lives (logos is Greek for meaning). Given the Freudian emphasis at the time, he challenged the preoccupation with conflicts between drives and instincts and argued that neuroses emerge from existential problems, from challenges in living in a sometimes senseless world. He was also critical of theories of homeostasis, "What man actually needs is not a tensionless state, but rather the striving and struggling for a worthwhile goal, a freely chosen task. What he needs is not the discharge of tension at any cost but the call of a potential meaning waiting to be fulfilled by him" (p.110).

Frankl's enormous gift and immense legacy was to help all who followed see something that had never before been so perfectly articulated - when confronted with a hopeless situation, what matters most is to transform it into something with meaning. We can always determine our stance toward hopelessness: "It is not freedom from conditions, but is the freedom to take a stand toward the conditions" (p.132). He closed his memoir this: "As a professor in two fields, neurology and psychiatry, I am fully away of the extent to which man is subject to biological, psychological, and sociological conditions. But in addition to being a professor in two fields I am a survivor of four camps - concentration camps that is - and as such I also bear witness to the unexpected extent to which man is capable of defying and braving even 
the worst conditions conceivable" (p.132). He had found the ultimate high ground in understanding human resilience.

\section{Conclusion}

This article has emphasized the importance of meaning making and self realization as people deal with the trials and tribulations life delivers to them. Using a formulation of eudaimonic well-being as guide, numerous empirical examples of resilience were reviewed. These dealt with finding purpose and meaning, experiencing personal growth, and having close personal ties with others in dealing with social inequalities, the challenges of aging, and specific life challenges, such as child abuse, cancer, and widowhood. An important message of these examples is that health benefits appear to follow for those who find and sustain well-being, despite the existential challenges of living.

The latter half of the article distilled life narratives from three heroic exemplars of resilience. The point of these case examples is to showcase in the actual context of major life challenges how it is done - that is, how experiences are interpreted and meanings are made as one endures dramatic adversity. Their insights reveal the force of human motivation to prevail over hardship as well as powerful paradoxes about the human condition - namely, the unimagined insights and gains that can follow from encounters with the worst life can deliver. These revelations, in turn, bring clarity and direction to realization of personal capacities. Consistent with the theme of this special issue, an overarching message is that social relationships, past and present, are an undeniable thread throughout human tales of resilience.

\section{References}

Adler NE, Stewart J. Health disparities across the lifespan: Meaning, methods, and mechanisms. Annals of the New York Academy of Sciences. 2010; 1186(1):5-23. [PubMed: 20201865]

Allport, GW. Pattern and growth in personality. New York, NY: Holt, Rinehart, \& Winston; 1961.

Aristotle. The Nicomachean Ethics. Ross, D., translator. New York: Oxford University Press; 1925.

Boyle PA, Barnes LL, Buchman AS, Bennett DA. Purpose in life is associated with mortality among community-dwelling older persons. Psychosomatic Medicine. 2009; 71(5):574-579. [PubMed: 19414613]

Boyle PA, Buchman AS, Wilson RS, Yu L, Schneider JA, Bennett DA. Effect of purpose in life on the relation between Alzheimer disease pathologic changes on cognitive function in advanced age. JAMA Psychiatry. 2012; 69(5):499-506.

Bühler C. The curve of life as studied in biographies. Journal of Applied Psychology. 1935; 43:653673.

Bühler, C.; Massarik, F., editors. The course of human life. New York: Springer; 1968.

Carver CS. Resilience and thriving: Issues, models, and linkages. Journal of Social Issues. 1998; 54:245-266.

Centers for Disease Control and Prevention. National diabetes fact sheet: National estimates and general information on diabetes and prediabetes in the United States. Atlanta, GA: U.S. Department of Health and Human Services; 2011.

Chen E, Miller GE, Lachman ME, Gruenewald TL, Seeman TE. Protective factors for adults from low-childhood socioeconomic circumstances: The benefits of shift-and-persist for allostatic load. Psychosomatic Medicine. 2012; 74(2):178-186. [PubMed: 22286848]

Cohen S, Janicki-Deverts D, Chen E, Matthews KA. Childhood socioeconomic status and adult health. Annals of the New York Academy of Sciences. 2010; 1186(1):37-55. [PubMed: 20201867] 
Costanzo ES, Ryff CD, Singer BH. Psychosocial adjustment among cancer survivors: Findings from a national survey of health and well-being. Health Psychology. 2009; 28(2):147-156.10.1037/ a0013221 [PubMed: 19290706]

Cotter KA, Lachman ME. Psychosocial and behavioural contributors to health: Age-related increases in physical disability are reduced by physical fitness. Psychology \& Health. 2010; 25(7):805-820. [PubMed: 20204968]

Epel ES, McEwen BS, Ickovics JR. Embodying psychological thriving: Physical thriving in response to stress. Journal of Social Issues. 1998; 54(2):301-322.

Erikson EH. Identity and the life cycle: Selected papers. Psychological Issues. 1959; 1:1-171.

Frankl, VE.; Lasch, I. Man's search for meaning: An introduction to logotherapy. Boston, MA: Beacon Press; 1992. Originally published 1959

Friedman EM, Ryff CD. Living well with medical comorbidities: A biopsychosocial perspective. Journals of Gerontology. Series B, Psychological Sciences and Social Sciences. 2012; 67(5):535544.

Garmezy N. Children at risk: The search for the antecedents of schizophrenia: II. Ongoing research programs, issues, and intervention. Schizophrenia Bulletin. 1974; 1(9):55-125. [PubMed: 4619496]

Garmezy N. Resiliency and vulnerability of adverse developmental outcomes associated with poverty. American Behavioral Scientist. 1991; 34:416-430.

Garmezy N, Masten AS, Tellegen A. The study of stress and competence in children: A building block for developmental psychopathology. Child Development. 1984; 55:97-111. [PubMed: 6705637]

Greenfield EA. Felt obligation to help others as a protective factor against losses in psychological well-being following functional decline in middle and later life. Journals of Gerontology. Series B, Psychological Sciences and Social Sciences. 2009; 64(6):723.

Greenfield EA, Marks N. Formal volunteering as a protective factor for older adults' psychological well-being. Journals of Gerontology. Series B, Psychological Sciences and Social Sciences. 2004; 59B(5):S258-S264.

Greenfield EA, Marks NF. Identifying experiences of physical and psychological violence in childhood that jeopardize mental health in adulthood. Child Abuse \& Neglect. 2010; 34(3):161171. [PubMed: 20223518]

Helgeson, VS.; Lopez, L. Social support and growth following adversity. In: Reich, JW.; Zautra, AJ.; Hall, JS., editors. Handbook of adult resilience. New York: Guilford Press; 2010. p. 309-330.

Jahoda, M. Current concepts of positive mental health. New York, NY: Basic Books; 1958.

Jung, CG. Modern man in search of a soul. Dell, WS.; Baynes, CF., translators. New York: Harcourt, Brace \& World; 1933.

Keyes CLM, Shmotkin D, Ryff CD. Optimizing well-being: The empirical encounter of two traditions. Journal of Personality \& Social Psychology. 2002; 82(6):1007-1022. [PubMed: 12051575]

Klohnen EC. Conceptual analysis and measurement of the construct of ego-resiliency. Journal of Personality and Social Psychology. 1996; 70(5):1067-1079. [PubMed: 8656335]

Luthar, SS. Resilience in development: A synthesis of research across five decades. In: Cicchetti, D.; Cohen, DJ., editors. Developmental psychopathology, Vol. 3: Risk, disorder, and adaptation. 2nd. Hobokin, NJ: John Wiley \& Sons, Inc.; 2006. p. 739-795.

Luthar SS. Vulnerability and resilience: A study of high-risk adolescents. Child Development. 1991; 62(3):600-616. [PubMed: 1914628]

Luthar SS, Cicchetti D, Becker B. The construct of resilience: A critical evaluation and guidelines for future work. Child Development. 2000; 71:543-562. [PubMed: 10953923]

Lyubomirsky, S.; Della Porta, MD. Boosting happiness, buttressing resilience: Results from cognitive and behavioral interventions. In: Reich, JW.; Zautra, AJ.; Hall, JS., editors. Handbook of adult resilience. New York, NY US: Guilford Press; 2010. p. 450-464.

Markus, HR.; Ryff, CD.; Curhan, KB.; Palmersheim, KA. In their own words: Well-being at midlife among high school-educated and college-educated adults. In: Brim, OG.; Ryff, CD.; Kessler, RC., editors. How healthy are we?: A national study of well-being at midlife. Chicago, IL: The University of Chicago Press; 2004. p. 273-319. 
Mathabane, M. Kaffir boy: An autobiography. New York: Free Press; 1986.

Mattlin, B. Miracle boy grows up: How the disability rights revolution saved my sanity. New York, NY: Skyhorse Publishing; 2012.

Maslow, AH. Toward a psychology of being. 2nd. New York, NY: Van Nostrand; 1968.

Masten, AS. Resilience in development: Implications of the study of successful adaptation for developmental psychopathology. In: Cicchetti, D., editor. The emergence of a discipline: Rochester symposium on developmental psychopathology. Vol. 1. Hillsdale, NJ: Erlbaum; 1989. p. 261-294.

Masten AS. Learning from children who overcome adversity. PsycCRITIQUES. 1991; 36(2):101-102.

Masten AS, Best KM, Garmezy N. Resilience and development: Contributions from the study of children who overcome adversity. Development and Psychopathology. 1990; 2(4):425-444.

Mayer, JD.; Faber, MA. Personal intelligence and resilience: Recovery in the shadow of broken connections. In: Reich, JW.; Zautra, AJ.; Hall, JS., editors. Handbook of adult resilience. New York, NY US: Guilford Press; 2010. p. 94-111.

McLaughlin S, Connell C, Heeringa S, Li L, Roberts J. Successful aging in the United States: Prevalence estimates from a national sample of older adults. The Journals of Gerontology. Series B, Psychological Sciences and Social Sciences. 2010; 65B(2):216.

Mill, JS. Autobiography. London, England: Penguin; 1989. Original work published 1893

Miller GE, Lachman ME, Chen E, Gruenewald TL, Karlamangla AS, Seeman TE. Pathways to resilience: Maternal nurturance as a buffer against the effects of childhood poverty on metabolic syndrome at midlife. Psychological Science. 2011; 22(12):1591-1599. [PubMed: 22123777]

Morozink JA, Friedman EM, Coe CL, Ryff CD. Socioeconomic and psychosocial predictors of interleukin-6 in the MIDUS national sample. Health Psychology. 2010; 29(6):626-635. [PubMed: 20954777]

Neugarten, BL. The awareness of middle age. In: Neugarten, BL., editor. Middle age and aging. Chicago: University of Chicago Press; 1968.

Neugarten, BL. Personality change in late life: A developmental perspective. In: Eisodorfer, C.; Lawton, MP., editors. The psychology of adult development and aging. Washington, DC: American Psychological Association; 1973. p. 311-335.

Neitzsche, F. Twilight of the idols. New York: Penguin Classics; 1889/1990.

Norton, DL. Personal destinies: A philosophy of ethical individualism. Princeton, NJ: Princeton University Press; 1976.

Ong AD, Fuller-Rowell TE, Bonanno GA. Prospective predictors of positive emotions following spousal loss. Psychology and Aging. 2010; 25(3):653-660. [PubMed: 20853971]

Ong AD, Fuller-Rowell TE, Bonanno GA, Almeida DM. Spousal loss predicts alterations in diurnal cortisol activity through prospective changes in positive emotion. Health Psychology. 2011; 30(2): 220-227. [PubMed: 21401256]

Pargament, KI.; Cummings, J. Anchored by faith: Religion as a resilience factor. In: Reich, JW.; Zautra, AJ.; Hall, JS., editors. Handbook of adult resilience. New York, NY US: Guilford Press; 2010. p. 193-210.

Park CL. Stress-related growth and thriving through coping: The roles of personality and cognitive processes. Journal of Social Issues. 1998; 54(2):267-277.

Pitzer LM, Fingerman KL. Psychosocial resources and associations between childhood physical abuse and adult well-being. Journals of Gerontology. Series B, Psychological Sciences and Social Sciences. 2010; 65B(4):425.

Pudrovska T. What makes you stronger: Age and cohort differences in personal growth after cancer. Journal of Health and Social Behavior. 2010; 51(3):260-273. [PubMed: 20943589]

Rafaeli, E.; Hiller, A. Self-complexity: A source of resilience? In: Reich, JW.; Zautra, AJ.; Hall, JS., editors. Handbook of adult resilience. New York, NY US: Guilford Press; 2010. p. 171-192.

Reich, JW.; Zautra, AJ.; Hall, JS., editors. Handbook of Adult Resilience. New York: The Guilford Press; 2010. 
Robins RW, John OP, Caspi A, Moffitt TE, Stouthamer-Loeber M. Resilient, overcontrolled, and undercontrolled boys: Three replicable personality types. Journal of Personality \& Social Psychology. 1996; 70:157-171. [PubMed: 8558407]

Rogers CR. The interpersonal relationship: The core of guidance. Harvard Educational Review. 1962; 32(4):416-429.

Russell, B. The conquest of happiness. New York, NY: Liveright; 1958. Original work published 1930

Rutter M. Psychosocial resilience and protective mechanisms. American Journal of Orthopsychiatry. 1987; 57:316-331. [PubMed: 3303954]

Rutter, M. Psychosocial resilience and protective mechanisms. In: Rolf, J.; Masten, AS.; Cicchetti, D.; Neuchterlein, KH.; Weintraub, S., editors. Risk and protective factors in the development of psychopathology. New York: Cambridge University Press; 1990. p. 181-214.

Ryff C, Friedman E, Fuller-Rowell T, Love G, Miyamoto Y, Morozink J, Tsenkova V. Varieties of resilience in MIDUS. Social and Personality Psychology Compass. 2012; 6(11):792-806. [PubMed: 24058379]

Ryff, CD. Adult personality development and the motivation for personal growth. In: Kleiber, D.; Maehr, M., editors. Advances in motivation and achievement (Vol. 4, Motivation and adulthood). Greenwich, CT: JAI Press; 1985. p. 55-92.

Ryff CD. Happiness is everything, or is it? Explorations on the meaning of psychological well-being. Journal of Personality and Social Psychology. 1989; 57(6):1069-1081.

Ryff CD, Keyes CLM. The structure of psychological well-being revisited. Journal of Personality \& Social Psychology. 1995; 69(4):719-727. [PubMed: 7473027]

Ryff CD, Keyes CLM, Hughes DL. Status inequalities, perceived discrimination, and eudaimonic well-being: Do the challenges of minority life hone purpose and growth? Journal of Health \& Social Behavior. 2003; 44(3):275-291. [PubMed: 14582308]

Ryff CD, Singer BH. Best news yet on the six-factor model of well-being. Social Science Research. 2006; 35:1103-1119.

Sarte, JP. Being and nothingness. Oxford, England: Philosophical Library; 1956.

Seeman TE, Miller-Martinez DM, Stein Merkin S, Lachman ME, Tun PA, Karlamangla AS. Histories of social engagement and adult cognition: Midlife in the U.S. Study. Journals of Gerontology. Series B, Psychological Sciences and Social Sciences. 2011; 66B(Suppl 1):i141-i152.

Springer KW, Pudrovska T, Hauser RM. Does psychological well-being change with age? Longitudinal tests of age variations and further exploration of the multidimensionality of Ryff's model of psychological well-being. Social Science Research. 2011; 40(1):392-398. [PubMed: 21218154]

Staudinger, UM.; Marsiske, M.; Baltes, PB. Resilience and reserve capacity in later adulthood: Potentials and limits of development across the life span. In: Cicchetti, D.; Cohen, D., editors. Developmental psychopathology (Band 2: Risk, disorder and adaptation). New York, NY: Wiley; 1995. p. 801-847.

Tedeschi, RG.; Calhoun, LG. Trauma and transformation: Growing in the aftermath of suffering. Thousand Oaks, CA: Sage; 1995.

Tedeschi, RG.; Park, CL.; Calhoun, LG., editors. Posttraumatic growth: Positive changes in the aftermath of crisis. Mahwah, NJ: Erlbaum; 1998.

Ungar M. Annual research review: What is resilience within the social ecology of human development? Journal of Child Psychology and Psychiatry. 2013; 54:348-366. [PubMed: 23215898]

Werner EE. Resilience in development. Current Directions in Psychological Science. 1995; 4:81-85.

Werner, EE.; Smith, RS. Kauai's children come of age. Honolulu, HI: University of Hawaii Press; 1977.

Werner, EE.; Smith, RS. Overcoming the odds: High risk children from birth to adulthood. Ithaca, NY: Cornell University Press; 1992. 